\title{
A Functional Interaction of Sodium and Calcium in the Regulation of NMDA Receptor Activity by Remote NMDA Receptors
}

\author{
Wen-Kuan Xin, ${ }^{1,3}$ Chun L. Kwan, ${ }^{1,3}$ Xiao-Han Zhao, ${ }^{1,3}$ Jindong Xu, ${ }^{1,3}$ Richard P. Ellen, ${ }^{2}$ Christopher A. G. McCulloch, ${ }^{2}$ \\ and Xian-Min $\mathrm{Yu}^{1,3,4}$ \\ ${ }^{1}$ The Department of Oral Physiology and ${ }^{2}$ Canadian Institutes of Health Research Group in Matrix Dynamics, Faculty of Dentistry, University of Toronto, \\ Toronto, Ontario M5G 1G6, Canada, ${ }^{3}$ Centre for Addiction and Mental Health, Toronto, Ontario M5T 1R8, Canada, and ${ }^{4}$ Department of Biomedical Science, \\ College of Medicine, Florida State University, Tallahassee, Florida 32306-4300
}

The NMDA receptor is an important subtype glutamate receptor that acts as a nonselective cation channel highly permeable to both calcium $\left(\mathrm{Ca}^{2+}\right)$ and sodium $\left(\mathrm{Na}^{+}\right)$. The activation of NMDA receptors produces prolonged increases of intracellular $\mathrm{Ca}^{2+}$ concentration $\left(\left[\mathrm{Ca}^{2+}\right]_{\mathrm{i}}\right)$ and thereby triggers downstream signaling pathways involved in the regulation of many physiological and pathophysiological processes. Previous studies have focused on how $\mathrm{Ca}^{2+}$ or $\mathrm{Na}^{+}$affects NMDA receptor activity in isolation. Specifically, $\left[\mathrm{Ca}^{2+}\right]_{\mathrm{i}}$ increase may downregulate NMDA channels and thus is considered an important negative feedback mechanism controlling NMDA receptor activity, whereas an increase in intracellular $\mathrm{Na}^{+}$concentration $\left(\left[\mathrm{Na}^{+}\right]_{\mathrm{i}}\right)$ may upregulate NMDA channel activity. Thus so that the activity-dependent regulation of NMDA receptors and neuroplasticity may be further understood, a critical question that has to be answered is how an individual NMDA receptor may be regulated when both of these ionic species flow into neurons during the same time period via neighboring activated NMDA receptors. Here we report that the gating of a NMDA channel is regulated by the activation of remote NMDA receptors via a functional $\mathrm{Na}^{+}-\mathrm{Ca}^{2+}$ interaction and that during the activation of NMDA receptors $\mathrm{Na}^{+}$influx potentiates $\mathrm{Ca}^{2+}$ influx on one hand and overcomes $\mathrm{Ca}^{2+}$-induced inhibition of NMDA channel gating on the other hand. Furthermore, we have identified that a critical increase $(5 \pm 1 \mathrm{~mm})$ in $\left[\mathrm{Na}^{+}\right]_{\mathrm{i}}$ is required to mask the effects of $\mathrm{Ca}^{2+}$ on NMDA channel gating in cultured hippocampal neurons. Thus cross talk between NMDA receptors mediated by a functional $\mathrm{Na}^{+}-\mathrm{Ca}^{2+}$ interaction is a novel mechanism regulating NMDA receptor activity.

Key words: NMDA channel gating; intracellular sodium and calcium; single-channel activity; excitability; toxicity; synaptic plasticity

\section{Introduction}

The NMDA type glutamate receptor/channel plays important roles in the regulation of fast excitatory synaptic transmission and activity-dependent neuroplasticity (Dingledine et al., 1999). NMDA channels are highly permeable to both sodium $\left(\mathrm{Na}^{+}\right)$ and calcium $\left(\mathrm{Ca}^{2+}\right)$ (Mayer and Westbrook, 1987; McBain and Mayer, 1994; Dingledine et al., 1999). The activation of NMDA receptors may produce a prolonged increase in intracellular $\mathrm{Ca}^{2+}$ concentration $\left(\left[\mathrm{Ca}^{2+}\right]_{\mathrm{i}}\right)$ and trigger downstream signaling pathways (Mody and MacDonald, 1995; Dingledine et al., 1999). It has been demonstrated that an increase in $\left[\mathrm{Ca}^{2+}\right]_{\mathrm{i}}$ may downregulate NMDA channels in central neurons cultured from embryos and acutely isolated from adult animals. The $\mathrm{Ca}^{2+}$ -

Received March 16, 2004; revised Nov. 12, 2004; accepted Nov. 14, 2004.

This work was supported by grants from the Canadian Institutes of Health Research (CIHR), the Ontario Neurotrauma Foundation, and the Heart and Stroke Foundation of Ontario to X.-M.Y. and by a CIHR group grant to the CIHR Group in Matrix Dynamics. We thank Drs. Z.-G. Xiong and X.-P. Chu for technical assistance and Drs. M. W. Salter, H. Van Tol, and Z.-P. Feng for critical comments on this manuscript.

Correspondence should be addressed to Xian-Min Yu, College of Medicine, Room 2300-C, Florida State University, 1115 West Call Street, Tallahassee, FL 32306-4300. E-mail: xianmin.yu@med.fsu.edu or xianmin.yu@utoronto.ca. DOI:10.1523/JNEUROSCI.3791-04.2005

Copyright $\odot 2005$ Society for Neuroscience $\quad$ 0270-6474/05/250139-10\$15.00/0 induced downregulation of NMDA channel activity is considered an important negative feedback mechanism to control NMDA receptor activity (Mayer and Westbrook, 1987; McBain and Mayer, 1994; Kyrozis et al., 1996; Dingledine et al., 1999).

$\mathrm{Na}^{+}$is the major cation in the extracellular space and can enter cells via a variety of routes, including permeation through ligand-gated (e.g., glutamate) and voltage-gated cation channels and uptake through membrane exchangers as well as through gradient-driven cotransport (Nicholls and Attwell, 1990; Hille, 1992; Rose and Ransom, 1997). In the nervous system $\mathrm{Na}^{+}$influx regulates neuronal excitability and is responsible for the initiation and propagation of action potentials (Taylor and Dudek, 1982; Hille, 1992). Studies using fluorescence ratio imaging of $\mathrm{Na}^{+}$indicator dye have reported that electrical activity, particularly bursting activity, dramatically increases $\left[\mathrm{Na}^{+}\right]_{\mathrm{i}}$ in neurons (Callaway and Ross, 1997; Rose and Ransom, 1997; Rose and Konnerth, 2001). Rose and Konnerth (2001) demonstrated that short bursts of synaptic stimulation may cause an increase in $\left[\mathrm{Na}^{+}\right]$of up to $40 \mathrm{~mm}$ in postsynaptic spines and their adjacent dendrites. During tetanic stimulation that induces synaptic longterm potentiation, $\left[\mathrm{Na}^{+}\right]$in synaptically active spines may reach $100 \mathrm{~mm}$ (Rose and Konnerth, 2001). They also demonstrated that 
the $\left[\mathrm{Na}^{+}\right]$increases in spines and dendrites induced by synaptic stimulation are mediated mainly by $\mathrm{Na}^{+}$entry through NMDA channels and are concurrent to synaptic potentials and backpropagating action potentials (Rose and Konnerth, 2001).

Intracellular $\mathrm{Na}^{+}$has been shown to be an upregulator of NMDA receptors, such that raising $\left[\mathrm{Na}^{+}\right]_{\mathrm{i}}$ or activating $\mathrm{Na}^{+}{ }_{-}$ permeable channels may enhance NMDA receptor-mediated currents (Yu and Salter, 1998). Thus the activity of a NMDA receptor may be regulated by other NMDA receptors via the actions of $\mathrm{Ca}^{2+}$ and/or $\mathrm{Na}^{+}$entering neurons. Because intracellular $\mathrm{Na}^{+}$and $\mathrm{Ca}^{2+}$ act in an opposing manner on NMDA channel activity and all previous studies have focused only on the effects of either $\mathrm{Ca}^{2+}$ or $\mathrm{Na}^{+}$, a compelling question is how the activity of an individual NMDA channel may be regulated when both ionic species flow into neurons during the same time period through activated remote NMDA receptors. To address this issue, we investigated the regulation of NMDA channel gating by the activation of remote NMDA receptors in cell-attached patches and consequently revealed a novel functional relationship of $\mathrm{Na}^{+}$and $\mathrm{Ca}^{2+}$ influxes in the regulation of NMDA receptors, which may be important for the understanding of mechanisms underlying activity-dependent neuroplasticity.

\section{Materials and Methods}

Primary neuron culture and NMDA single-channel current recordings. Primary cultures from the hippocampus were prepared from fetal Wistar rats (embryonic day 17-19) as described previously (Lei et al., 2002). In brief, hippocampal tissue was dissociated mechanically by trituration and plated onto $35 \mathrm{~mm}$ collagen-coated culture dishes at a density of $<1 \times 10^{6}$ cells $/ \mathrm{ml}$. Hippocampal neurons were used for electrophysiological recordings $8-14 \mathrm{~d}$ after plating.

NMDA receptor-mediated single-channel currents were recorded in the cell-attached configuration. Hippocampal cultures were bathed in a standard extracellular solution containing the following (in $\mathrm{mM}$ ): 100 $\mathrm{Na}_{2} \mathrm{SO}_{4}, 10 \mathrm{Cs}_{2} \mathrm{SO}_{4}, 1.2$ or $4.8 \mathrm{CaCl}_{2}, 25$ HEPES, 32 glucose, 0.001 TTX, 0.003 glycine, $\mathrm{pH} 7.35$, and $310-320 \mathrm{mOsm}$. Free $\mathrm{Ca}^{2+}$ concentration of the extracellular solution was at either 0.3 or $1.2 \mathrm{~mm}$ as confirmed by measurement with a $\mathrm{Ca}^{2+}$-selective electrode (Thermo Electron, Beverly, MA). The resting potential of neurons bathed with extracellular solutions of these two different $\mathrm{Ca}^{2+}$ concentrations was $60 \pm 5 \mathrm{mV}(n=$ 4 ) as measured with sharp electrodes filled with $3 \mathrm{M} \mathrm{KCl}$. A Ca ${ }^{2+}$-free extracellular solution was made from the standard extracellular solution containing $0.5 \mathrm{~mm} \mathrm{Na}{ }^{+}$-BAPTA and no added $\mathrm{Ca}^{2+}$. To reduce noise (McLarnon and Curry, 1990) and prevent cell damage (Choi, 1993; Yu et al., 1997; Yu and Salter, 1998) during NMDA receptor activation, we replaced $\mathrm{K}^{+}$and $\mathrm{Cl}^{-}$in the solution by $\mathrm{Cs}^{+}$and $\mathrm{SO}_{4}{ }^{2-}$, respectively. $\mathrm{Na}_{2} \mathrm{SO}_{4}$ in the solutions was replaced with $\mathrm{Cs}_{2} \mathrm{SO}_{4}$ to make extracellular solutions with various $\mathrm{Na}^{+}$concentrations as indicated. Recording pipettes were made from thin-walled borosilicate glass capillaries (World Precision Instruments, Sarasota, FL) pulled to tips of 1-2 $\mu \mathrm{m}$ and fire polished. The pipettes were filled with the same extracellular solution (except as indicated) used for bathing neurons (DC resistance, 8-10 $\mathrm{M} \Omega$ ) but also containing $10 \mu \mathrm{M}$ NMDA and $3 \mu \mathrm{M}$ glycine to evoke NMDA receptor-mediated currents.

During experiments the cultures were placed in a recording chamber on an inverted microscope (Axiovert S100 TV, Carl Zeiss, Göttingen, Germany) equipped with a $64 \times$ Varel Relief Contrast System. The image was magnified an additional $30 \times$ and displayed on a 17 inch TV monitor so that the morphology of the cell soma and major processes of neurons could be monitored during the recording period. Changes in cell morphology (such as cell swelling) could be detected readily by changing the osmolarity of the extracellular solution and thus lead to alterations in NMDA channel activity (Paoletti and Ascher, 1994). None of the bath solutions and experimental manipulations produced significant changes in size or shape of the cell soma and/or main processes.

Single-channel recording methods and criteria used to ensure that recordings were indeed from NMDA channels have been described in detail previously (Wang et al., 1996; Yu et al., 1997; Yu and Salter, 1998). In brief, NMDA-mediated single-channel currents were recorded with a patch potential of $70 \mathrm{mV}$ from the reversal potential, except where indicated. Currents recorded were filtered at $10 \mathrm{kHz}(-3 \mathrm{~dB})$ with an Axopatch 1D amplifier (Axon Instruments, Foster City, CA), digitized at 33 $\mathrm{kHz}$, and stored onto videotape. The main conductance levels of $\sim 80 \%$ of recorded channels were in the range of $40-60 \mathrm{pS}$, with the remainder in the range of 10-30 vpS, as typically is observed in our and others' studies (Gibb and Colquhoun, 1992; Stern et al., 1994; Yu et al., 1997; Yu and Salter, 1998). The recorded currents were abolished by the bath application of the lipophilic NMDA channel blocker MK-801 $(2 \mu \mathrm{M})$, confirming that NMDA receptor-mediated single-channel currents were recorded (Yu and Salter, 1998). After 3 to $5 \mathrm{~min}$ of recordings, which served as a control, the tested agents such as L-aspartate or NMDA dissolved in the same extracellular solution were bath applied to patched neurons. NMDA-mediated single-channel currents then were recorded for another 5 to $10 \mathrm{~min}$. Because the bath application of L-aspartate or NMDA to neurons may cause cell depolarization, the holding potential was readjusted to maintain a patch potential of $70 \mathrm{mV}$ from the reversal potential of recorded channels.

Methods for single-channel data analysis have been described in detail previously (Wang et al., 1996; Yu et al., 1997; Yu and Salter, 1998). In brief, the data stored on videotape were replayed, filtered at $2-5 \mathrm{kHz}(-3$ $\mathrm{dB}, 8$ pole Bessel), and sampled continuously onto a computer at $20 \mathrm{kHz}$ with pClamp6 software (Axon Instruments). Because only one main conductance level of channel openings was recorded in most patches, the channel open probability and duration of channel openings and closings were determined off-line by using a 50\% crossing threshold. Distributions of dwell times were fit with the sum of multiple exponential components by using the Levenberg-Marquardt least-squares method. The usefulness of adding exponential components was assessed by using an $F$ test (De Koninck and Mody, 1994) and also by visual inspection. Channel activity during the entire application period of tested agents (at least 3-5 $\mathrm{min}$ ), which is from the time after readjustment of patch potential at the same level $(70 \mathrm{mV})$ from the reversal potential after the start of the agent application, was compared with that for a similar period immediately preceding the application. The bursts, clusters, and superclusters of channel openings (Edmonds and Colquhoun, 1995) were identified according to critical times $\left(t_{\mathrm{c}}\right)$, where each $t_{\mathrm{c}}$ is defined by the following:

$$
1-e^{-t_{\mathrm{c}} / \tau_{\mathrm{s}}}=e^{-t_{\mathrm{c}} / \tau_{\mathrm{m}}}
$$

$\tau_{\mathrm{s}}$ and $\tau_{\mathrm{m}}$ are the time constants of short and intermediate gap lengths (Colquhoun and Sakmann, 1985; Gibb and Colquhoun, 1992); the durations of bursts, clusters, and superclusters of channel openings were calculated by using pClamp6 software.

The measurement of $\left[\mathrm{Na}^{+}\right]_{i}$ and $\left[\mathrm{Ca}^{2+}\right]_{i} \cdot\left[\mathrm{Na}^{+}\right]_{\mathrm{i}}$ and $\left[\mathrm{Ca}^{2+}\right]_{\mathrm{i}}$ were measured with the $\mathrm{Na}^{+}$-sensitive and $\mathrm{Ca}^{2+}$-sensitive fluorescent dyes sodium-binding benzofuran isophthalate (SBFI) and fura-2, respectively, using a 346/380 $\mathrm{nm}$ pair of excitation wavelengths from monochromators and single-photon counting methods as described previously (Bibby and McCulloch, 1994; Yu and Salter, 1998). Neurons cultured on poly-D-lysine-coated glass coverslips were incubated either with fura-2 AM $(5 \mu \mathrm{M})$ or SBFI AM $(10 \mu \mathrm{M})$ mixed with pluronic F-127 $(20 \% \mathrm{w} / \mathrm{v} ; 1: 1)$ and dissolved in the extracellular solutions used for single-channel recordings for 40 or $90 \mathrm{~min}$ at room temperature. Then the coverslips were washed and transferred to a perfusion chamber on a Nikon Diaphot II inverted microscope. The 346/380 nm fluorescence ratios were recorded in the soma region of neurons by using Deltascan System (Photon Technology International, South Brunswick, NJ). $\left[\mathrm{Na}^{+}\right]_{\mathrm{i}}$ and $\left[\mathrm{Ca}^{2+}\right]_{\mathrm{i}}$ were measured according to the following equation: $\left[\mathrm{Na}^{+}\right]$or $\left[\mathrm{Ca}^{2+}\right]=K_{\mathrm{D}}\left[\left(R-R_{\min }\right) /\left(R_{\max }-R\right)\right]\left(380_{\max } / 380_{\min }\right)$. Calibration of $\mathrm{Na}^{+}$in neurons required the addition of $10 \mu \mathrm{M}$ of monensin and $1.5 \mathrm{~mm}$ of ouabain [used to equilibrate intracellular with extracellular $\left[\mathrm{Na}^{+}\right]$and inhibit the high level of $\mathrm{Na}^{+} / \mathrm{K}^{+}$ATPase activity present in neurons (Rose and Ransom, 1997)] into a calibration solution containing 0,20 , or $150 \mathrm{~mm} \mathrm{Na}^{+}$, which was applied sequentially to neurons to determine $R_{\min }, R$ for $20 \mathrm{mM} \mathrm{Na}^{+}$, and $R_{\max }$. The $K_{\mathrm{D}}$ of SBFI obtained in this manner from tested neurons was $11.6 \mathrm{~mm}$. Calibration of $\mathrm{Ca}^{2+}$ in 


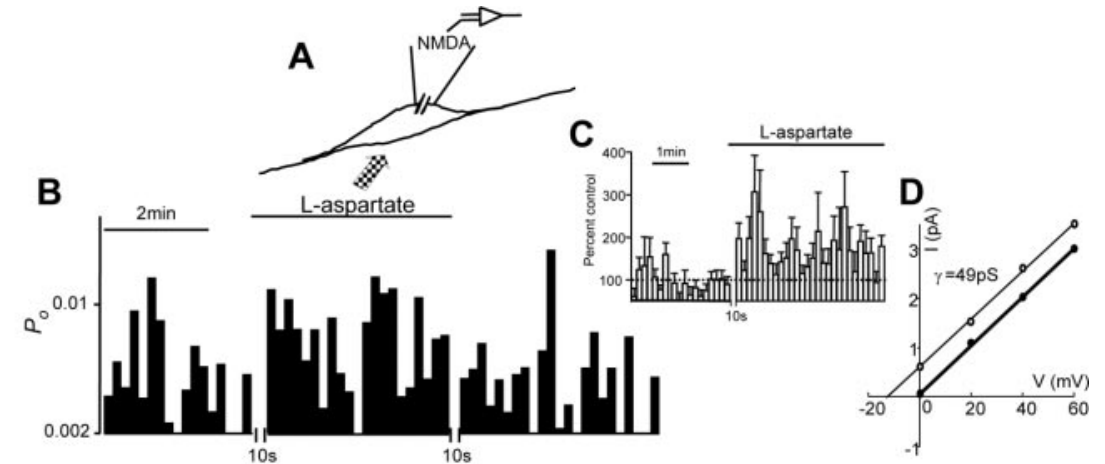

E

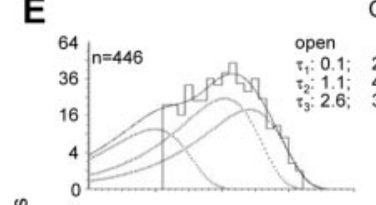

Control

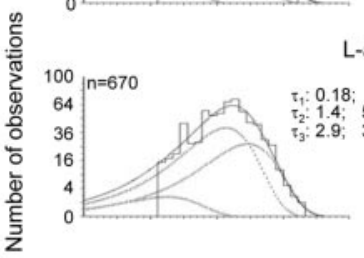

L-aspartate

$20 \%{ }^{36} \mid n=445$

- Control

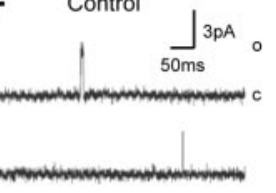

$64 n=669$
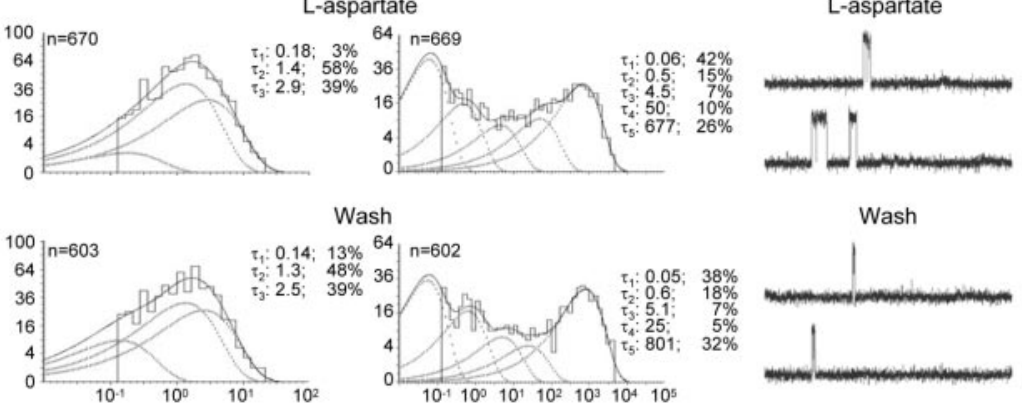

Dwell-time (ms)

Wash

$13 \%$
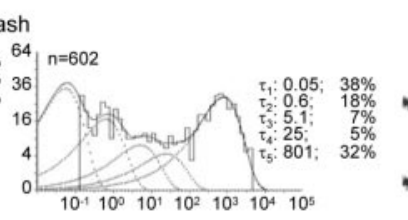

Wash

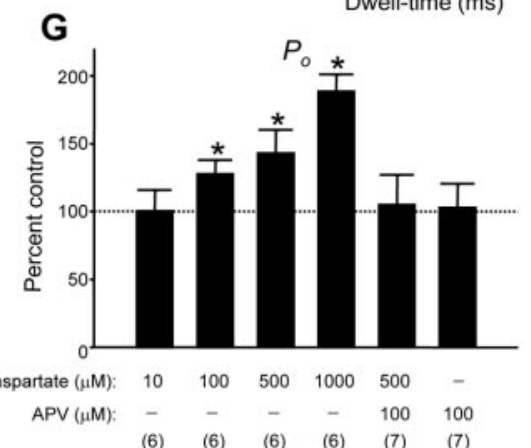

$\begin{array}{lllll}\text { (6) } & \text { (6) } & \text { (6) } & \text { (6) } & \text { (7) }\end{array}$

Figure 1. Enhancement of NMDA channel gating induced by the activation of remote NMDA receptors. $A$, The recording configuration used to investigate the effects of remote NMDA receptor activation by the bath application of the NMDA receptor agonist $\mathrm{L}$-aspartate on the NMDA channel within the membrane patch. $B$, A record of NMDA single-channel open probability $\left(P_{0}\right.$; bin, $10 \mathrm{sec}$ ) before and during stimulation of remote NMDA receptors by the bath application of the NMDA receptor agonist L-aspartate $(500 \mu \mathrm{M})$. The break during the recording was required for adjusting the patch potential to $70 \mathrm{mV}$ from the NMDA channel reversal potential after L-aspartate was applied to neurons. C, The average single-channel open probability (bin, $10 \mathrm{sec} ; 7$ patches) normalized by the mean values of $P_{0}$ before $L$-aspartate application. $D$, The graph shows the $I-V$ relationship for singlechannel currents before (open circles) and during L-aspartate application (filled circles). The lines that are depicted represent least-squares regression lines. $E$, Dwell-time histograms of open and shut times were compiled before (top), during (middle), and after (bottom) the bath application of L-aspartate. In the dwell-time histograms, the solid line shows the Marquardt least-squares fit for the histogram, the dashed lines indicate individual exponential components, and $n$ is the number of events. There were three open components and five closing components. $\tau$, Time constant; percentage values indicate relative areas of each component. $F$, Representative single-channel current traces are illustrated before, during, and after the application of $\mathrm{L}$-aspartate. 0, Open level; c, closed level. G, Summarized data (mean \pm SEM) showing that increases in the concentration of $\mathrm{L}$-aspartate applied to remote NMDA receptors increased the $P_{0}$ and mean open time $\left(t_{0}\right)$ of recorded NMDA channels. Values in parentheses indicate the number of patches tested; ${ }^{*} p<0.05$, Wilcoxon test.

neurons required the addition of $6 \mu \mathrm{M}$ ionomycin $\left[\mathrm{a} \mathrm{Ca}^{2+}\right.$ ionophore (Bibby and McCulloch, 1994; Kyrozis et al., 1996)] into a calibration solution containing 0 or $2 \mathrm{mM} \mathrm{Ca}^{2+}$ sequentially applied to neurons to determine $R_{\min }$ and $R_{\max }$, respectively. The $K_{\mathrm{D}}$ of fura- 2 in neurons was in accordance with values described previously (Kyrozis et al., 1996). The mean concentrations of intracellular $\mathrm{Na}^{+}$and $\mathrm{Ca}^{2+}$ were calculated before and during a 300 sec period immediately after NMDA receptor agonist application. All chemicals used were obtained from Sigma (St. Louis, MO) except for ionomycin (Calbiochem, La Jolla, CA) and BAPTA, BAPTA-AM, SBFI-AM, fura-2 AM, and monensin (all of which were purchased from Molecular Probes, Eugene, OR).

\section{Results}

Upregulation or downregulation of NMDA channel gating by the activation of remote NMDA receptors is dependent on the interaction of $\mathrm{Na}^{+}$ and $\mathrm{Ca}^{2+}$ influxes

NMDA single-channel activity was recorded in the cell-attached configuration before and during the bath application of NMDA receptor agonist L-aspartate (10$1000 \mu \mathrm{M}$ ), which was used to activate remote NMDA receptors located outside the membrane patch (Fig. 1A). Consistent with previous findings (Edmonds and Colquhoun, 1995; Yu et al., 1997; Yu and Salter, 1998), recordings of single-channel activity before the activation of remote NMDA receptors indicated that the open time of recorded channels ranged from $<0.1 \mathrm{msec}$ to longer than several tens of milliseconds, and the shut time ranged from $<0.1 \mathrm{msec}$ to longer than several thousands of milliseconds. By fitting the open and shut time distribution histograms, we found three components with time constants (mean $\pm \mathrm{SE} ; n=24$ patches) of $0.12 \pm 0.01 \mathrm{msec}$ (relative area, $51 \pm 4 \%), 1.6 \pm 0.1 \mathrm{msec}(29 \pm 3 \%)$, and $3.7 \pm 0.2 \mathrm{msec}(20 \pm 2 \%)$ in the open time and five components with time constants of $0.12 \pm 0.01 \mathrm{msec}$ (relative area, $39 \pm 3 \%), 1.0 \pm 0.12 \mathrm{msec}(17 \pm 1 \%)$, $14 \pm 1.3 \mathrm{msec}(10 \pm 0.7 \%), 487 \pm 66 \mathrm{msec}$ $(16 \pm 2 \%)$, and $1656 \pm 218 \mathrm{msec}(18 \pm$ $2 \%$ ) in the shut time. The overall channel open probability (ratio of total open time vs recording time) and mean open time of recorded NMDA channels were $0.0049 \pm$ 0.0005 and $2.2 \pm 0.1 \mathrm{msec}$, respectively.

We found that bath application of the NMDA receptor agonist L-aspartate may change NMDA channel activity in a concentration-dependent manner (Fig. $1 G)$. A significant increase in NMDA channel gating occurred when $100 \mu \mathrm{M}$ L-aspartate was bath applied. An example of recorded NMDA channel open probability and averaged open probability of the channels for a period of $10 \mathrm{sec}$ each before and during the bath application of NMDA receptor agonist L-aspartate $(500 \mu \mathrm{M})$ is shown in Figure $1, B$ and $C$, respectively. The bath application of L-aspartate or NMDA to neurons causes cell depolarization and hence a parallel shift of the current-voltage $(I-V)$ relationship (Fig. $1 D)$, indicating that 
there is no change in single-channel conductance but rather a change in the reversal potential. Therefore, the holding potential was readjusted (the time break shown in Fig. $1 B, C$ ) to maintain a patch potential of $70 \mathrm{mV}$ from the reversal potential of recorded channels. We found that the bath application of L-aspartate may increase NMDA channel activity immediately (Fig. $1 B, C$ ). During the bath application of L-aspartate the short open component was reduced while the shortest closing component was increased (Fig. $1 E)$. The overall channel open probability and mean open time increased significantly (Fig. 1G).

Consistent with our previous finding, the application of $30 \mathrm{mM} \mathrm{K}^{+}$to neurons in the presence of the voltage-gated $\mathrm{Na}^{+}$channel blocker tetrodotoxin (TTX; $1 \mu \mathrm{M}$ ) produced cell depolarization comparable to that induced by the application of $500 \mu \mathrm{M}$ L-aspartate, but it did not affect NMDA channel activity (Yu and Salter, 1998) (data not shown). Furthermore, we found that, whereas the $500 \mu \mathrm{M}$ L-aspartate application produced increases in the overall channel open probability in all six recorded patches by $15-100 \%$ of that before L-aspartate application (i.e., control), the overall channel open probability during $500 \mu \mathrm{M}$ L-aspartate application increased by $17-28 \%$ of controls in four of seven recorded patches and decreased by $16-20 \%$ in the three remaining patches when $100 \mu \mathrm{M}$ aminophosphonovalerate (APV; a NMDA receptor antagonist) was coapplied. Although $100 \mu \mathrm{M} \mathrm{APV}$ application did not abolish completely the effects produced by L-aspartate application in every patch that was recorded, on average no significant change in NMDA channel activity was noted during L-aspartate application (Fig. 1). Taken together with the finding that the bath application of $100 \mu \mathrm{M}$ APV alone did not affect recorded NMDA channel activity significantly (Fig. $1 G$ ), we conclude that NMDA channel gating can be upregulated via the activation of remote NMDA receptors.

To understand mechanisms underlying the effects of remote NMDA receptor activation, we additionally characterized the functional roles of intracellular $\mathrm{Na}^{+}$and $\mathrm{Ca}^{2+}$. Our previous study has shown that NMDA channel activity may be downregulated by the activation of remote NMDA receptors when $\mathrm{Na}^{+}$in the extracellular solution is replaced with the membrane-impermeant cation $N$-methyl-D-glucamine (NMDG) (Yu and Salter, 1998). However, it remained unclear whether the reduction of NMDA channel gating during the activation of remote NMDA receptors was induced by a reduction of $\left[\mathrm{Na}^{+}\right]_{\mathrm{i}}$, which can be produced by efflux of intracellular $\mathrm{Na}^{+}$, and/or by some other unknown mechanisms. To answer this question, we investigated the effects of activation of remote NMDA receptors on NMDA channel activity when the $\mathrm{Na}^{+}$gra-
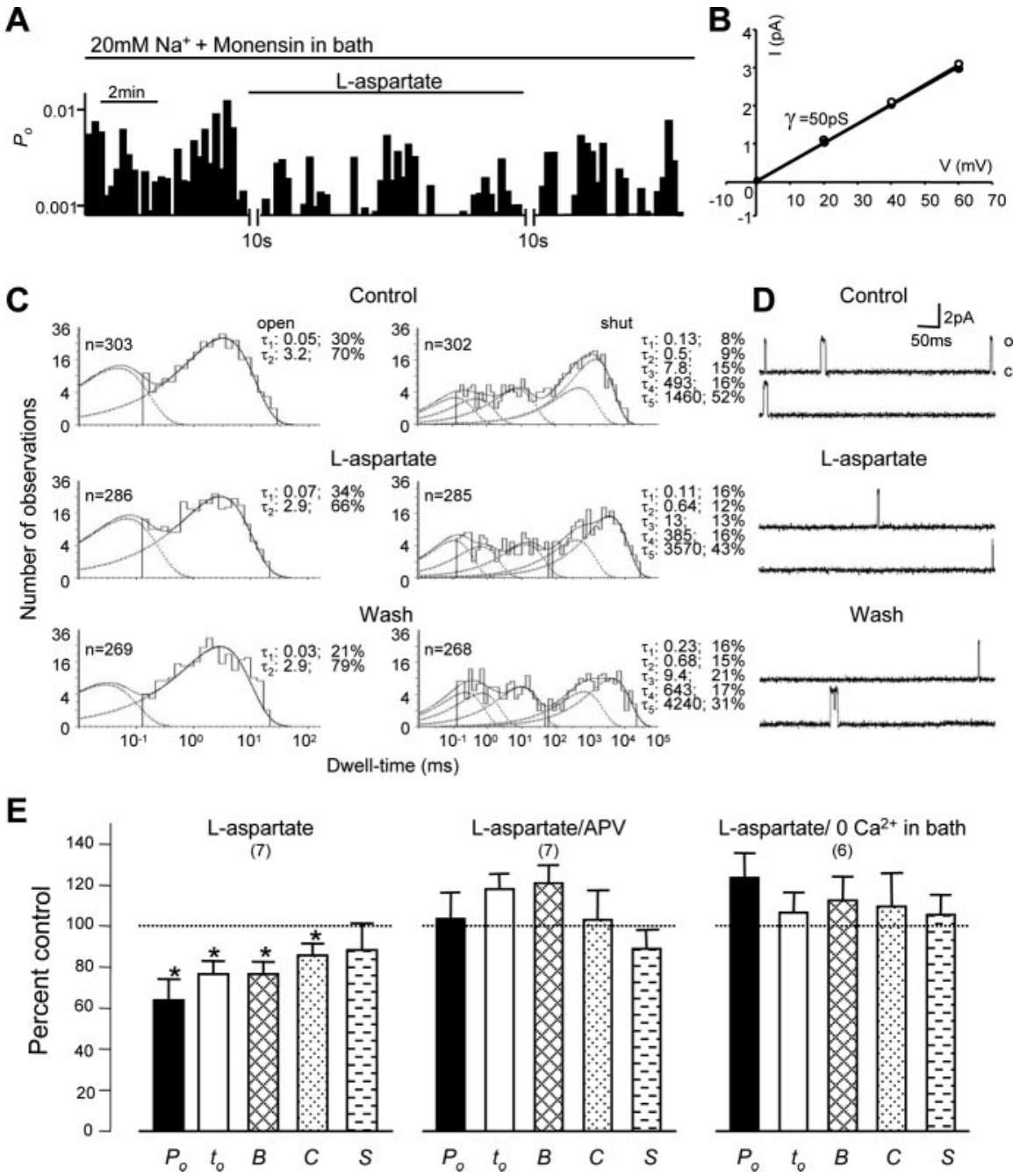

Figure 2. The downregulation of NMDA channel gating by remote NMDA receptors. $A$, An example of NMDA channel open probability $\left(P_{0} ;\right.$ bin, $\left.10 \mathrm{sec}\right)$ recorded from neurons bathed with an extracellular solution in which [ $\mathrm{Na}^{+}$] was reduced to $20 \mathrm{~mm}$ with $\mathrm{Cs}^{+}$replacement and the inclusion of the $\mathrm{Na}^{+}$ionophore monensin $(10 \mu \mathrm{m}) . B$, The graph shows the $I-V$ relationship for single-channel currents before (open circles) and during (filled circles) L-aspartate application. The lines represent least-squares the bath application of L-aspartate. In the dwell-time histograms, the solid line shows the Marquardt least-squares fit for the istogram, the dashed lines indicate individual exponential components, and $n$ is the number of events. $\tau$, Time constant; the before, during, and after the application of L-aspartate. 0, Open level; $c$, closed level. $E$, Summarized data (mean \pm SEM) outlining , forfects of remote NMDA receptor activation by the bath application of L-aspartate on $P_{0}$, mean open time $\left(t_{0}\right)$, burst containing $20 \mathrm{~mm} \mathrm{Na}^{+}$and $10 \mu \mathrm{m}$ monensin. The inhibitory effects could be prevented by the coapplication of NMDA receptor antagonist APV (100 $\mu \mathrm{m}$; L-aspartate/APV) or by removal of $\mathrm{Ca}^{2+}$ in the extracellular solution (L-aspartate/0 $\mathrm{Ca}^{2+}$ in bath). Values in parentheses indicate the number of patches tested; ${ }^{*} p<0.05$ (Wilcoxon test).

dient across the cell membrane was decreased by reducing $\left[\mathrm{Na}^{+}\right]$ to $20 \mathrm{~mm}$ and including the $\mathrm{Na}^{+}$ionophore monensin $(10 \mu \mathrm{M})$ in the extracellular solution. Figure $2 A-D$ displays an example of NMDA channel activity recorded under these conditions. We found that the application of $500 \mu \mathrm{M}$ L-aspartate in six of seven recorded patches produced decreases in NMDA channel activity with a reduction of the long open component (Fig. $2 C$ ). The decreases in the overall channel open probability varied from 21 to $63 \%$ of control. On average, the overall channel open probability and mean open time were reduced to $64 \pm 10$ and $77 \pm 6 \%$ of controls, and the duration of bursts and clusters was reduced to $77 \pm 5$ and $86 \pm 6 \%$ of controls, respectively (Fig. $2 E$ ). In the presence of $100 \mu \mathrm{M} \mathrm{APV}, \mathrm{L}$-aspartate application produced re- 
ductions in the overall channel open probability of 27 and $38 \%$ in two of seven recorded patches, increases in the overall channel open probability of 27 and $61 \%$ of control in two patches, and slight changes (either increases or decreases) of $<10 \%$ of control in three patches. On average, there was no significant change in NMDA channel activity recorded from neurons bathed with the extracellular solution containing $20 \mathrm{mM} \mathrm{Na}^{+}$and monensin during L-aspartate application in the presence of $100 \mu \mathrm{M}$ APV (Fig. $2 E)$. Thus we conclude that the inhibitory effects on NMDA channel gating induced by the bath application of L-aspartate could be blocked by bath coapplication of the NMDA receptor antagonist APV, indicating that the activation of remote NMDA receptors downregulates NMDA channel activity under the condition in which $\mathrm{Na}^{+}$influx was blocked by reducing the $\mathrm{Na}^{+}$ gradient across the cell membrane. Also, we found that blocking $\mathrm{Ca}^{2+}$ influx by removal of $\mathrm{Ca}^{2+}$ from the extracellular bath solution could prevent the inhibition of NMDA channel gating induced by the activation of remote NMDA receptors. During the activation of remote NMDA receptors the overall channel open probability, mean open time, and the duration of burst, clusters, and superclusters were $124 \pm 11,107 \pm 10$, and $113 \pm 12,110 \pm$ 16 , and $106 \pm 10 \%$ of controls, respectively (Fig. $2 E$ ). These data suggest that $\mathrm{Ca}^{2+}$ influx may play an important role in the downregulation of NMDA channel gating induced by the activation of remote NMDA receptors in neurons bathed with the extracellular solution containing $20 \mathrm{mM} \mathrm{Na}^{+}$and $\mathrm{Na}^{+}$ionophore monensin.

\section{A modest $\mathrm{Ca}^{2+}$ influx may inhibit NMDA receptors when $\mathrm{Na}^{+}$influx is reduced}

In light of our observations that NMDA receptor/channel gating may be upregulated or downregulated by the activation of remote NMDA receptors via the actions of $\mathrm{Na}^{+}$or $\mathrm{Ca}^{2+}$ entering neurons, it was of considerable interest to determine how the balance of intracellular $\mathrm{Na}^{+}$and $\mathrm{Ca}^{2+}$ controls these effects on NMDA channel gating. To this end we measured $\left[\mathrm{Na}^{+}\right]_{\mathrm{i}}$ and $\left[\mathrm{Ca}^{2+}\right]_{\mathrm{i}}$ in the soma region of neurons bathed with an extracellular solution containing $10 \mathrm{mM} \mathrm{Na}{ }^{+}, 0.3 \mathrm{mM} \mathrm{Ca}^{2+}$, and no $\mathrm{Na}^{+}$ionophore monensin (Fig. $3 A, B$ ). We found that NMDA receptor activation produced $\left[\mathrm{Na}^{+}\right]_{\mathrm{i}}$ increases ranging from 0 to $2 \mathrm{mM}(0.8 \pm 0.2$ $\mathrm{mM} ; n=9 ;$ mean $\pm \mathrm{SE}$ ) and $\left[\mathrm{Ca}^{2+}\right]_{\mathrm{i}}$ increases ranging from 2.7 to $56 \mathrm{~nm}(35 \pm 9 \mathrm{~nm} ; n=7)$. Under these conditions we recorded NMDA single-channel activity in cell-attached patches and found that the activation of remote NMDA receptors produced significant decreases in NMDA channel activity (Fig. 3C,E). The overall channel open probability and mean open time were reduced to $62 \pm 13$ and $69 \pm 14 \%$ of controls, and the durations of bursts and clusters were reduced to $67 \pm 11$ and $70 \pm 7 \%$ of controls, respectively (Fig. 3E). Thus these observations additionally confirmed that NMDA channel gating was inhibited by the activation of remote NMDA receptors when $\mathrm{Na}^{+}$influx was reduced.

We then investigated whether the inhibitory effect induced by $\mathrm{Ca}^{2+}$ influx through activated remote NMDA receptors may be affected by local $\mathrm{Na}^{+}$influx through recorded NMDA channels. NMDA channel activity was recorded by using two different concentrations of $\mathrm{Na}^{+}$in the recording pipettes. The overall channel open probability $(0.0021 \pm 0.0007 ; n=9$ patches $)$ of NMDA channels recorded with pipettes filled with an extracellular solution containing $10 \mathrm{mM} \mathrm{Na}^{+}$was significantly lower $(p<0.05$; Mann-Whitney test) than that of NMDA channels recorded with pipettes filled with an extracellular solution containing $200 \mathrm{mM}$ of $\mathrm{Na}^{+}(0.0065 \pm 0.0026 ; n=10$ patches $)$. Regardless of intra-
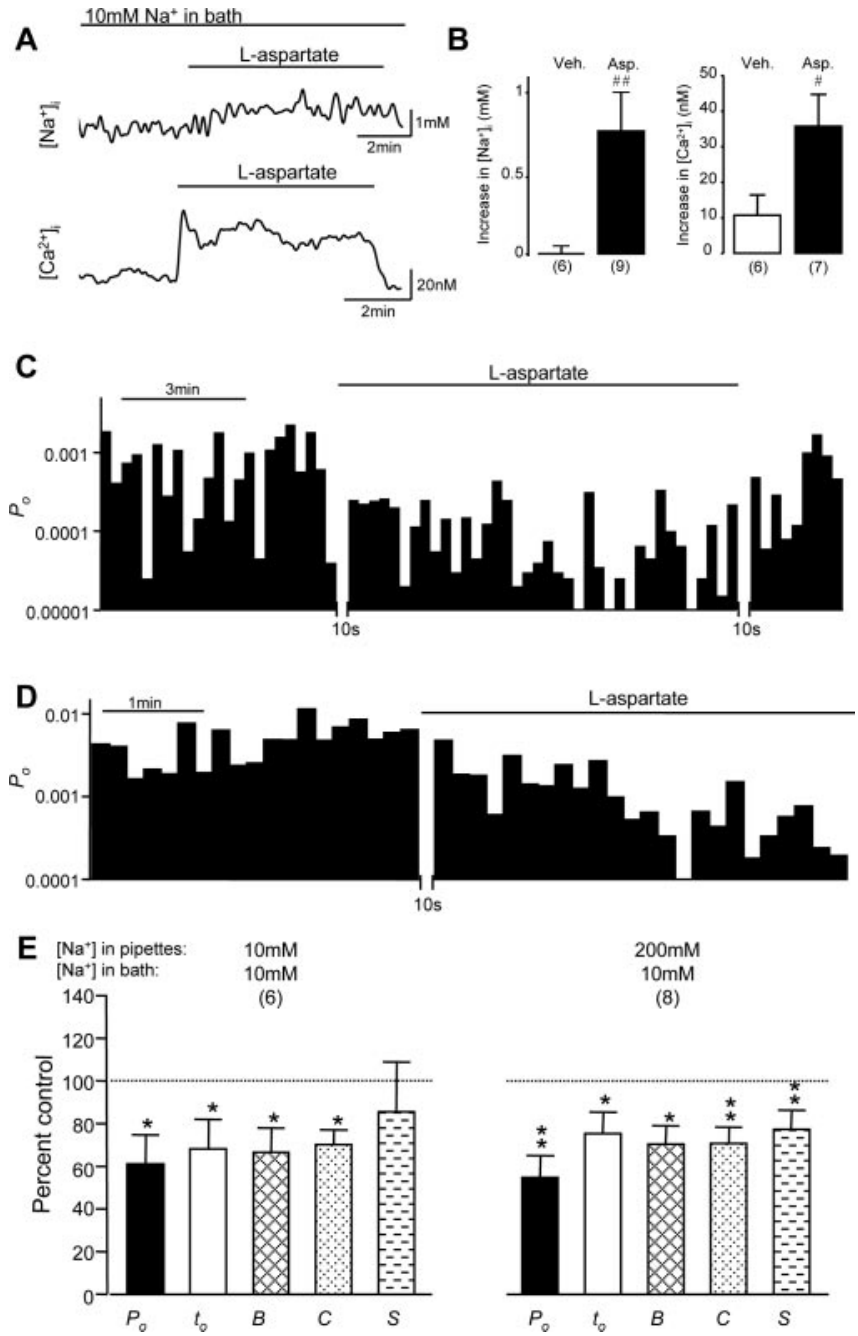

$200 \mathrm{mM}$

(8)

Figure 3. The downregulation of NMDA channel gating by remote NMDA receptors was not regulated by local $\mathrm{Na}^{+}$influx through recorded channels. $A$, Examples of traces of $\left[\mathrm{Na}{ }^{+}\right]_{\mathrm{i}}$ (top) and $\left[\mathrm{Ca}^{2+}\right]_{i}$ (bottom) recorded in the soma region of neurons bathed with the same extracellular solution used from electrophysiological recordings, containing $10 \mathrm{~mm} \mathrm{Na}{ }^{+}$and $0.3 \mathrm{~mm}$ $\mathrm{Ca}^{2+}$, before and during L-aspartate $(500 \mu \mathrm{m})$ application. $B$, Summarized data indicating changes induced by the application of vehicle (open bars) and L-aspartate (filled bars) on $\left[\mathrm{Na}^{+}\right]_{\mathrm{i}}$ (left) and $\left[\mathrm{Ca}^{2+}\right]_{\mathrm{i}}$ (right); ${ }^{\#} p<0.05 ;{ }^{\# \#} p<0.01$ (Mann-Whitney test) in a comparison between L-aspartate versus vehicle effects. Veh., Vehicle; Asp., L-aspartate. C, An example of NMDA channel open probability $\left(P_{0} ;\right.$ bin, $\left.10 \mathrm{sec}\right)$ recorded from neurons bathed with the extracellular solution containing $10 \mathrm{~mm} \mathrm{Na}{ }^{+}$but no monensin, using recording pipettes filled with the extracellular solution except that it contained $10 \mu \mathrm{m}$ NMDA. D, An example of NMDA channel open probability $\left(P_{0} ;\right.$ bin, $\left.10 \mathrm{sec}\right)$ recorded from neurons bathed with the standard extracellular solution containing $200 \mathrm{~mm} \mathrm{Na}^{+}$, using recording pipettes filled with the extracellular solution containing $10 \mathrm{~mm} \mathrm{Na}^{+}$and $10 \mu \mathrm{M}$ NMDA. E, Summarized data (mean \pm SEM) outlining the inhibitory effects of remote NMDA receptor activation produced by the bath application of L-aspartate on $P_{0}$, mean open time $\left(t_{0}\right)$, burst $(B)$, cluster $(C)$, and supercluster $(S)$ lengths of NMDA channels recorded by using pipettes filled with the standard extracellular solution containing $200 \mathrm{~mm} \mathrm{Na}^{+}$or with the extracellular solution containing $10 \mathrm{~mm} \mathrm{Na}^{+}$, also used to bathe the neurons. Values in parentheses indicate the number of patches tested; ${ }^{*} p<0.05$; ${ }^{* *} p<0.01$ (Wilcoxon test).

pipette $\mathrm{Na}^{+}$concentration, the activation of remote NMDA channels produced similar levels of NMDA channel gating inhibition (Fig. 3D,E).

We found that the activation of remote NMDA receptors also could cause an inhibition of ensemble currents. Figure 4 shows examples of alignment and summation of consecutive superclusters recorded from neurons bathed with extracellular solutions 

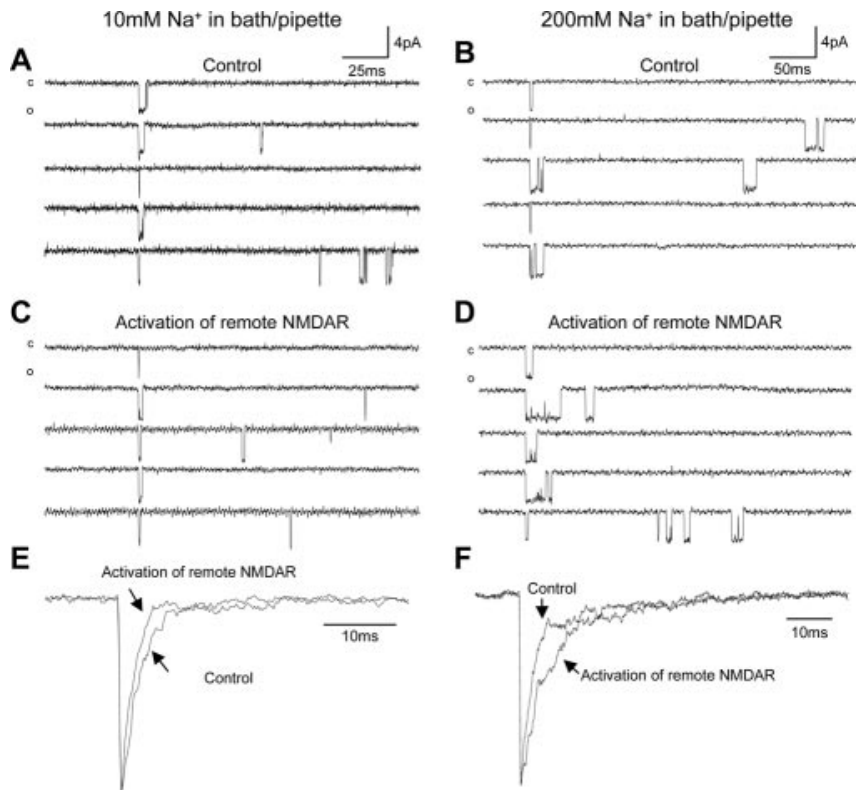

Figure 4. Ensemble NMDA currents were regulated by the activation of remote NMDA receptors. Shown are examples of the alignment of vertically flipped supercluster current traces at the start of the first openings of superclusters recorded before (control) and during the activation of remote NMDA receptors in neurons bathed with an extracellular solution containing 10 $\mathrm{mm} \mathrm{Na}^{+}(A, C)$ or $200 \mathrm{~mm} \mathrm{Na}^{+}(B, D)$. Recording pipettes were filled with the same extracellular solution used for bathing neurons except that it contained $10 \mu \mathrm{m}$ NMDA. c, Closed level; 0, open level. $E$, The corresponding ensemble currents produced by the summation of 100 and 95 consecutive superclusters recorded before (Control) and during the activation of remote NMDA receptors (NMDAR), examples of which are shown in $A$ and $C$, respectively. $F$, The corresponding ensemble currents produced by the summation of 114 and 153 consecutive superclusters recorded before (Control) and during the activation of remote NMDA receptors (NMDAR), examples of which are shown in $B$ and $D$, respectively. The ensemble currents were normalized by their peak amplitudes and superimposed to show the difference between the currents.

containing 10 or $200 \mathrm{mM} \mathrm{Na}^{+}$before and during the activation of remote NMDA receptors. Compared with the ensemble current before the activation of remote NMDA receptors, there was a shortened decay of the current during the activation of remote NMDA receptors when $\left[\mathrm{Na}^{+}\right]_{\mathrm{e}}$ was reduced to $10 \mathrm{~mm}$ (Fig. $4 E$ ). In contrast, a prolonged decay of the current during the activation of remote NMDA receptors was found in neurons bathed with the standard extracellular solution containing $200 \mathrm{mM} \mathrm{Na}^{+}$ (Fig. $4 F$ ).

\section{A $5 \pm 1 \mathrm{~mm}$ increase in intracellular sodium concentration $\left(\left[\mathrm{Na}^{+}\right]_{i}\right)$ represents a threshold required to mask the downregulation of NMDA channels by remote NMDA receptors}

We then investigated the effects of remote NMDA receptor activation when $\left[\mathrm{Na}^{+}\right]$in the extracellular bath solution, which contained $0.3 \mathrm{mM} \mathrm{Ca}^{2+}$, was increased to $20 \mathrm{~mm}$. We found that under this condition no significant change in NMDA channel gating could be produced by the activation of remote NMDA receptors (Fig. $5 A, B$ ). The overall channel open probability and mean open time were $106 \pm 6$ and $104 \pm 4 \%$ of controls, and the durations of bursts, clusters and superclusters were $110 \pm 6$, $114 \pm 11$, and $124 \pm 16 \%$ of controls, respectively (Fig. $5 B$ ). Interestingly, even as $\left[\mathrm{Ca}^{2+}\right]_{\mathrm{e}}$ was increased to $1.2 \mathrm{~mm}$, the activation of remote NMDA receptors produced no significant inhibition of channel gating (Fig. 5B). These findings strongly suggest that $\mathrm{Na}^{+}$influx modulates the regulation of NMDA receptors by intracellular $\mathrm{Ca}^{2+}$ and that possible changes in $\left[\mathrm{Na}^{+}\right]_{\mathrm{i}}$ induced
A
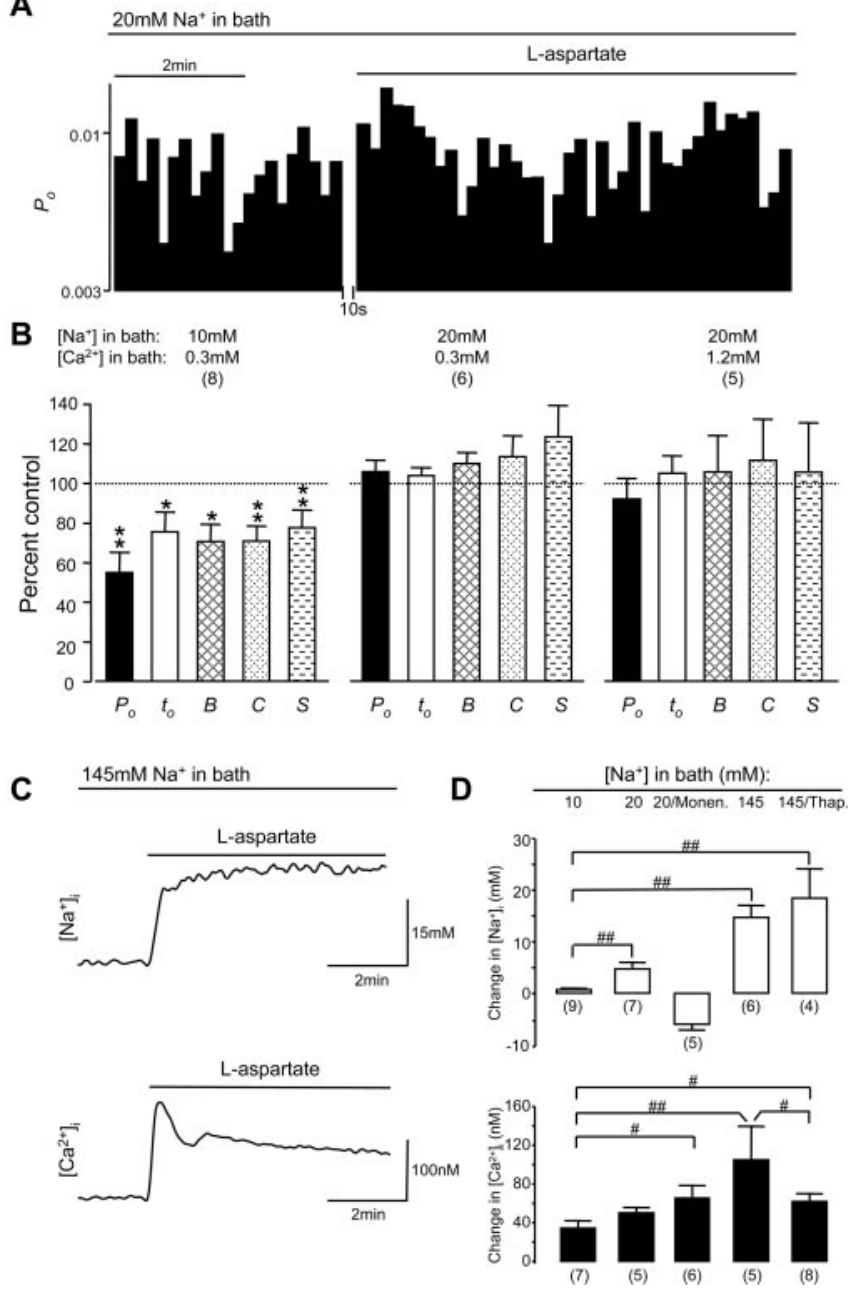

Figure 5. $\mathrm{Ca}^{2+}$ influx-induced downregulation of NMDA channel gating during activation of remote NMDA receptors could be overcome by a modest $\mathrm{Na}{ }^{+}$influx. $A$, An example of NMDA channel open probability $\left(P_{0} ;\right.$ bin, $\left.10 \mathrm{sec}\right)$ recorded from neurons bathed with an extracellular solution containing $20 \mathrm{~mm} \mathrm{Na}^{+}$and $0.3 \mathrm{~mm} \mathrm{Ca}{ }^{2+}$. B, Summarized data (mean \pm SEM) outlining the effects of remote NMDA receptor activation produced by the bath application of L-aspartate on $P_{0}$, mean open time $\left(t_{0}\right)$, burst $(\mathrm{B})$, cluster $(\mathrm{C})$, and supercluster $(\mathrm{S})$ lengths of NMDA channels recorded from neurons bathed with an extracellular solution containing $10 \mathrm{mM}$ $\mathrm{Na}^{+}$and $0.3 \mathrm{~mm} \mathrm{Ca}^{2+}$ or $20 \mathrm{~mm} \mathrm{Na}^{+}$and $0.3 \mathrm{~mm} \mathrm{Ca}^{2+}$ or $20 \mathrm{~mm} \mathrm{Na}{ }^{+}$and $1.2 \mathrm{~mm} \mathrm{Ca}^{2+}$. Values in parentheses indicate the number of patches tested. ${ }^{*} p<0.05$; ${ }^{* *} p<0.01$ (Wilcoxon test). C, Examples of traces of $\left[\mathrm{Na}^{+}\right]_{\mathrm{i}}$ (top) and $\left[\mathrm{Ca}^{2+}\right]_{\mathrm{i}}$ (bottom) recorded in the soma region of neurons bathed with the extracellular solution containing $0.3 \mathrm{~mm} \mathrm{Ca}^{2+}$ and $145 \mathrm{~mm} \mathrm{Na}{ }^{+}$ before and during L-aspartate $(500 \mu \mathrm{m})$ application. D, Summarized data indicating changes (mean $\pm \mathrm{SEM}$ ) in $\left[\mathrm{Na}^{+}\right]_{\mathrm{i}}$ (top) and $\left[\mathrm{Ca}^{2+}\right]_{\mathrm{i}}$ (bottom) induced by the activation of NMDA receptors in neurons bathed with extracellular solutions containing $0.3 \mathrm{mMCa}^{2+}$ and 10,20 , or $145 \mathrm{~mm} \mathrm{Na}^{+}$in the absence and presence of monensin $(10 \mu \mathrm{M})$ or $\mathrm{Ca}^{2+}$-ATPase inhibitor thapsigargin $(0.1 \mu \mathrm{M}) ;{ }^{\#} p<0.05$; ${ }^{\# \#} p<0.01$ (Mann-Whitney test) in a comparison between groups as indicated. Values in parentheses indicate the number of neurons tested.

by $20 \mathrm{~mm}$ of extracellular $\mathrm{Na}^{+}$during NMDA receptor activation is critical for controlling the regulation of NMDA receptors.

Measurement of $\left[\mathrm{Na}^{+}\right]_{\mathrm{i}}$ and $\left[\mathrm{Ca}^{2+}\right]_{\mathrm{i}}$ during NMDA receptor activation when neurons were bathed with the extracellular solution containing $20 \mathrm{mM} \mathrm{Na}^{+}$demonstrated $\left[\mathrm{Na}^{+}\right]_{\mathrm{i}}$ increases ranging from 1.4 to $10 \mathrm{~mm}(5 \pm 1 \mathrm{mM} ; n=7)$, which were significantly more than those found in neurons bathed with 10 $\mathrm{mM} \mathrm{Na}{ }^{+}$extracellular solution and $\left[\mathrm{Ca}^{2+}\right]_{\mathrm{i}}$ increases ranging from 32 to $62 \mathrm{~nm}(50 \pm 5 \mathrm{~nm} ; n=5)$ (Fig. $5 D)$. These data demonstrate a novel finding that the inhibitory effects induced by $\mathrm{Ca}^{2+}$ influx through remote NMDA receptors could be over- 
come by a modest $\mathrm{Na}^{+}$influx and that the increase in $\left[\mathrm{Na}^{+}\right]_{\mathrm{i}}$ of $5 \pm 1 \mathrm{~mm}$ may represent a critical threshold required to mask the inhibitory effects induced by $\mathrm{Ca}^{2+}$ influx on NMDA channels during the activation of remote NMDA receptors.

This finding also raised the question of why NMDA channel gating was decreased, but not enhanced, by the activation of remote NMDA receptors when basal $\left[\mathrm{Na}^{+}\right]_{\mathrm{i}}$ was increased $>5 \mathrm{mM}$ as in neurons bathed with an extracellular solution containing 20 $\mathrm{mM} \mathrm{Na}^{+}$and $10 \mu \mathrm{M}$ monensin (Fig. 2). To answer this question, we measured $\left[\mathrm{Na}^{+}\right]_{\mathrm{i}}$ and $\left[\mathrm{Ca}^{2+}\right]_{\mathrm{i}}$ and found that the basal $\left[\mathrm{Ca}^{2+}\right]_{\mathrm{i}}$ and $\left[\mathrm{Na}^{+}\right]_{\mathrm{i}}$ in these neurons were $84 \pm 18 \mathrm{~nm}$ and $16 \pm$ $2 \mathrm{~mm}$ and that the application of L-aspartate to these neurons produced a significant increase in $\left[\mathrm{Ca}^{2+}\right]_{\mathrm{i}}$ by $66 \pm 13 \mathrm{nM}(n=6)$ as well as a significant decrease in $\left[\mathrm{Na}^{+}\right]_{\mathrm{i}}$ by $5.8 \pm 1 \mathrm{mM}(n=5)$ (Fig. 5D) (supplemental Fig. 1, available at www.jneurosci.org as supplemental material). Taken together with the finding that removal of extracellular $\mathrm{Ca}^{2+}$ prevented the downregulation of NMDA channel gating by remote NMDA receptors, this indicates that the coincident $\left[\mathrm{Ca}^{2+}\right]_{\mathrm{i}}$ increase and $\left[\mathrm{Na}^{+}\right]_{\mathrm{i}}$ decrease induced by the activation of remote NMDA receptors may underlie the inhibition of NMDA channel gating induced by L-aspartate application to neurons bathed with an extracellular solution containing $20 \mathrm{mM} \mathrm{Na}^{+}$and monensin.

More importantly, we found that increasing $\left[\mathrm{K}^{+}\right]_{\mathrm{e}}$ by $30 \mathrm{~mm}$ in the solution containing $200 \mathrm{mM} \mathrm{Na}^{+}$and $1 \mu \mathrm{M}$ TTX, which produced no significant changes in NMDA single-channel gating, increased $\left[\mathrm{Na}^{+}\right]_{\mathrm{i}}$ and $\left[\mathrm{Ca}^{2+}\right]_{\mathrm{i}}$ by $7 \pm 2 \mathrm{mM}(n=7)$ and $48 \pm$ $19 \mathrm{~nm}(n=6)$, respectively (supplemental Fig. 2, available at www.jneurosci.org as supplemental material). This change in $\left[\mathrm{Na}^{+}\right]_{\mathrm{i}}$ and $\left[\mathrm{Ca}^{2+}\right]_{\mathrm{i}}$ is similar to measured $\left[\mathrm{Na}^{+}\right]_{\mathrm{i}}$ and $\left[\mathrm{Ca}^{2+}\right]_{\mathrm{i}}$ increases $(5 \pm 1 \mathrm{~mm}$ and $50 \pm 5 \mathrm{nM})$ induced by the activation of remote NMDA receptors, which produced no change in NMDA channel gating (Fig. $5 A, B, D$ ). Thus we believe that a $\mathrm{Na}^{+}$influx that increases $\left[\mathrm{Na}^{+}\right]_{\mathrm{i}}$ by $>5 \mathrm{mM}$ is critical for overcoming the effects of $\mathrm{Ca}^{2+}$ influx.

\section{$\mathrm{Na}^{+}$influx may enhance $\mathrm{Ca}^{2+}$ influx and also may mask the $\mathrm{Ca}^{2+}$-dependent inhibition of NMDA channels induced by the activation of remote NMDA receptors}

When extracellular $\left[\mathrm{Na}^{+}\right]$was increased additionally to $145 \mathrm{mM}$, the activation of NMDA receptors produced even greater increases in $\left[\mathrm{Na}^{+}\right]_{\mathrm{i}}(15 \pm 2 \mathrm{~mm} ; n=6)$ and $\left[\mathrm{Ca}^{2+}\right]_{\mathrm{i}}(105 \pm 35 \mathrm{nM}$; $n=5)$, which were significantly more than those induced by the activation of NMDA receptors in neurons bathed with extracellular solution containing $10 \mathrm{mM} \mathrm{Na}^{+}$(Fig. 5C,D). To determine whether the increase in $\left[\mathrm{Ca}^{2+}\right]_{i}$ was produced by increases in $\mathrm{Ca}^{2+}$ influx, we measured $\left[\mathrm{Ca}^{2+}\right]_{\mathrm{i}}$ during NMDA receptor activation in the presence of the $\mathrm{Ca}^{2+}$-ATPase inhibitor thapsigargin, which depletes intracellular stores of $\mathrm{Ca}^{2+}$ by blocking $\mathrm{Ca}^{2+}$ reuptake into stores. Thapsigargin $(0.1 \mu \mathrm{M})$ was bath applied to neurons at $20 \mathrm{~min}$ before the measurement of $\left[\mathrm{Ca}^{2+}\right]_{\mathrm{i}}$ or $\left[\mathrm{Na}^{+}\right]_{\mathrm{i}}$ and was maintained in the bath solution for the whole recording period. We found that thapsigargin application significantly reduced increases in $\left[\mathrm{Ca}^{2+}\right]_{i}$ during NMDA receptor activation when compared with those in the absence of thapsigargin (Fig. $5 D)$, but furthermore the increase in $\left[\mathrm{Ca}^{2+}\right]_{\mathrm{i}}(62 \pm 8 \mathrm{nM} ; n=8)$ during NMDA receptor activation in neurons bathed with an extracellular solution containing $145 \mathrm{mM} \mathrm{Na}^{+}$and thapsigargin was still significantly greater than that found in neurons bathed with an extracellular solution containing $10 \mathrm{mM} \mathrm{Na}^{+}$(Fig. 5D).

Although our previous study has shown that the upregulation of NMDA channel gating by the activation of remote NMDA receptors is not affected by the removal of $\mathrm{Ca}^{2+}$ in the extracel- lular bath solution (Yu and Salter, 1998), it remains unclear whether local $\mathrm{Ca}^{2+}$, which flows into recorded NMDA channels and sufficiently activates phosphatase regulation of NMDA receptors (Lieberman and Mody, 1994), or $\mathrm{Ca}^{2+}$ released from intracellular stores during the activation of NMDA receptors (Fig. 5D) may be involved in the regulation of NMDA channel gating. Therefore, we recorded NMDA single-channel activity by using pipettes filled with $\mathrm{Ca}^{2+}$-free extracellular solution from neurons that had been pretreated with BAPTA-AM (10 $\mu \mathrm{M}$ for 4 $\mathrm{hr}$ ) and bathed in the same extracellular solution containing no $\mathrm{Ca}^{2+}$. Figure $6 A-D$ displays an example of recorded NMDA channel activity. During the activation of remote NMDA receptors the long open component and shortest closing component of NMDA channels were increased. The overall channel open probability and mean open time increased to $137 \pm 11$ and $114 \pm 5 \%$ of controls, and the durations of bursts and clusters were increased to $120 \pm 10$ and $134 \pm 9 \%$ of controls, respectively (Fig. $6 E)$. Application of the lipophilic NMDA channel blocker MK801 (2 $\mu \mathrm{M}$ ) (Wong and Kemp, 1991; Yu and Salter, 1998; Dingledine et al., 1999) abolished single-channel currents (Fig. 6A) and confirmed that the recorded channel activity was NMDA receptor-mediated. The fact that no significant difference could be found in the effects produced by the activation of remote NMDA receptors as $\left[\mathrm{Ca}^{2+}\right]$ was changed (from 0 to $0.3-1.2 \mathrm{mM}$ ) in the extracellular solutions bathing neurons and filling recording electrodes (Fig. $6 E$ ) demonstrates that $\mathrm{Na}^{+}$influx through activated NMDA receptors not only may be able to enhance $\mathrm{Ca}^{2+}$ influx but also may mask $\mathrm{Ca}^{2+}$-induced inhibitory effects on NMDA channel gating (Fig. 7).

\section{Discussion}

The present study documents that NMDA channel activity may be upregulated or downregulated by remote NMDA receptors, depending on the amount of $\mathrm{Na}^{+}$and $\mathrm{Ca}^{2+}$ influx. If $\mathrm{Na}^{+}$influx is blocked, $\mathrm{Ca}^{2+}$ influx induced by the activation of remote NMDA receptors may inhibit NMDA channel gating. However, this inhibitory effect can be overcome by an increase in $\left[\mathrm{Na}^{+}\right]_{\mathrm{i}}$ of $>5 \mathrm{~mm}$. Thus there may be a functional $\mathrm{Na}^{+}-\mathrm{Ca}^{2+}$ interaction in the regulation of NMDA channels.

Further detailed investigations document that the effects of $\mathrm{Na}^{+}$and $\mathrm{Ca}^{2+}$ influx on NMDA channel gating during the activation of remote NMDA receptors cannot be explained simply by an algebraic sum of two opposite effects growing monotonically, because (1) $\mathrm{Ca}^{2+}$ influx required to downregulate NMDA receptors under the condition of no $\mathrm{Na}^{+}$influx is found to be much smaller than that during NMDA receptor activation under normal conditions; (2) a modest $\mathrm{Na}^{+}$influx, which produces a much smaller increase in $\left[\mathrm{Na}^{+}\right]_{\mathrm{i}}$ than that during NMDA receptor activation under normal conditions, blocks $\mathrm{Ca}^{2+}$ influx-induced inhibition of NMDA channels during the activation of remote NMDA receptors; (3) increases in $\mathrm{Na}^{+}$influx may enhance $\mathrm{Ca}^{2+}$ influx significantly during the activation of NMDA receptors; and (4) blocking increases in $\left[\mathrm{Ca}^{2+}\right]_{\mathrm{i}}$ both via $\mathrm{Ca}^{2+}$ release from intracellular stores and $\mathrm{Ca}^{2+}$ influx through both local and remote NMDA channels without blocking $\mathrm{Na}^{+}$influx did not produce any additional increase in NMDA receptor upregulation induced by the activation of remote NMDA receptors when compared with that recorded from neurons under normal conditions.

It has been reported that an ongoing $\mathrm{Ca}^{2+}$ inhibition of NMDA receptors may accompany the activation of NMDA channels and serve as a negative feedback mechanism to control NMDA channels (Mayer and Westbrook, 1987; McBain and Mayer, 1994; Kyrozis et al., 1996; Dingledine et al., 1999). How- 
ever, there seem to be no significant effects produced by $\mathrm{Ca}^{2+}$ influx on NMDA channel gating during the activation of remote NMDA receptors recorded from neurons bathed with a standard extracellular solution. Interestingly, when $\mathrm{Na}^{+}$influx was blocked, a modest $\mathrm{Ca}^{2+}$ influx during the activation of remote NMDA receptors produced a $35 \pm 9 \mathrm{nM}$ increase in $\left[\mathrm{Ca}^{2+}\right]_{\mathrm{i}}$ and significantly inhibited NMDA channel gating (Fig. 7). This $\mathrm{Ca}^{2+}$-induced inhibition of NMDA receptors could be prevented by a modest $\mathrm{Na}^{+}$influx, which produced an increase in $\left[\mathrm{Na}^{+}\right]_{\mathrm{i}}$ of $>5 \mathrm{~mm}$ (Fig. 7). Thus we have characterized a novel functional relationship of $\mathrm{Na}^{+}$and $\mathrm{Ca}^{2+}$ influxes in the regulation of NMDA receptor gating in cultured hippocampal neurons.

NMDA receptors are distributed widely in the CNS and are involved in many physiological and pathophysiological processes. Therefore, it will be very interesting to determine whether the functional relationship of $\mathrm{Na}^{+}$and $\mathrm{Ca}^{2+}$ influx in the regulation of NMDA receptor gating characterized in cultured hippocampal neurons also may be an important mechanism underlying the regulation of neuronal functions in the other regions of the CNS. Because neurons in culture preparations likely may not be representative of the neurons in vivo, the determination of whether a $5 \pm 1 \mathrm{~mm}$ increase in $\left[\mathrm{Na}^{+}\right]_{\mathrm{i}}$ also represents a threshold increase that enhances $\mathrm{Ca}^{2+}$ influx and also masks the effects of $\mathrm{Ca}^{2+}$ influx in vivo will be critical for understanding the regulation of activity-dependent neuroplasticity in vivo.

A number of mechanisms have been found to underlie the downregulation of NMDA channel gating by intracellular $\mathrm{Ca}^{2+}:$ (1) $\mathrm{Ca}^{2+}$-induced $\alpha$-actinin/cytoskeleton dissociation from the NR1 subunit of NMDA receptors (Krupp et al., 1999), (2) calmodulin activation, which binds to and inhibits NMDA channel activity (Ehlers et al., 1996; Wechsler and Teichberg, 1998; Zhang et al., 1998; Krupp et al., 1999), and (3) activation of the phosphatase calcineurin, which downregulates NMDA channel gating (Lieberman and Mody, 1994; Mulkey et al., 1994; Tong et al., 1995). Our findings suggest that there may be a functional $\mathrm{Na}^{+}-\mathrm{Ca}^{2+}$ interaction in the regulation of NMDA receptors (Fig. 7). NMDA channel gating may be decreased if $\mathrm{Na}^{+}$influx during the activation of remote NMDA receptors is less than that $(5 \pm 1 \mathrm{mM})$ required to overcome the effects induced by $\mathrm{Ca}^{2+}$ influx, whereas NMDA channel gating may be potentiated by the activation of remote $\mathrm{NMDA}$ receptors if $\mathrm{Na}^{+}$influx is more than that required to overcome the effects induced by $\mathrm{Ca}^{2+}$ influx (Fig. 7). Our data show that under physiological conditions there is a large $\mathrm{Na}^{+}$

A

C

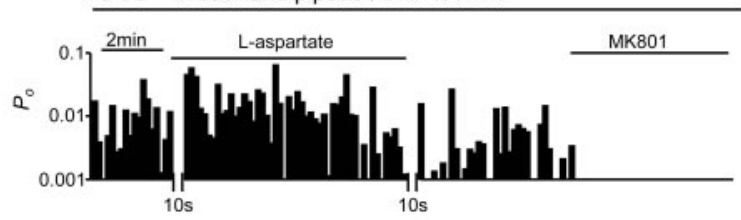

B
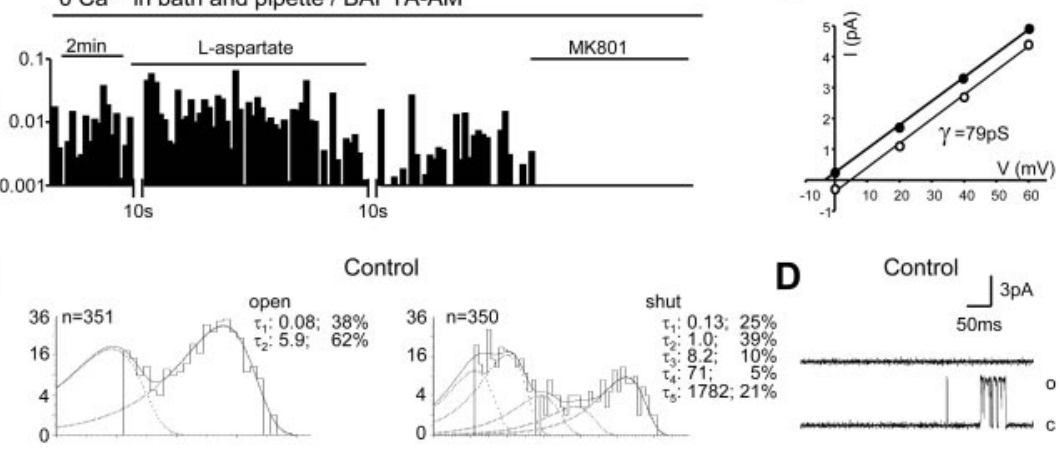

ntrol

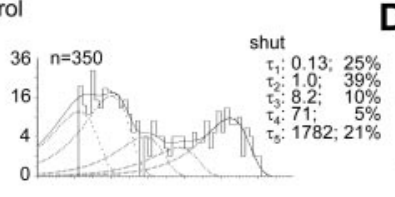

D Control
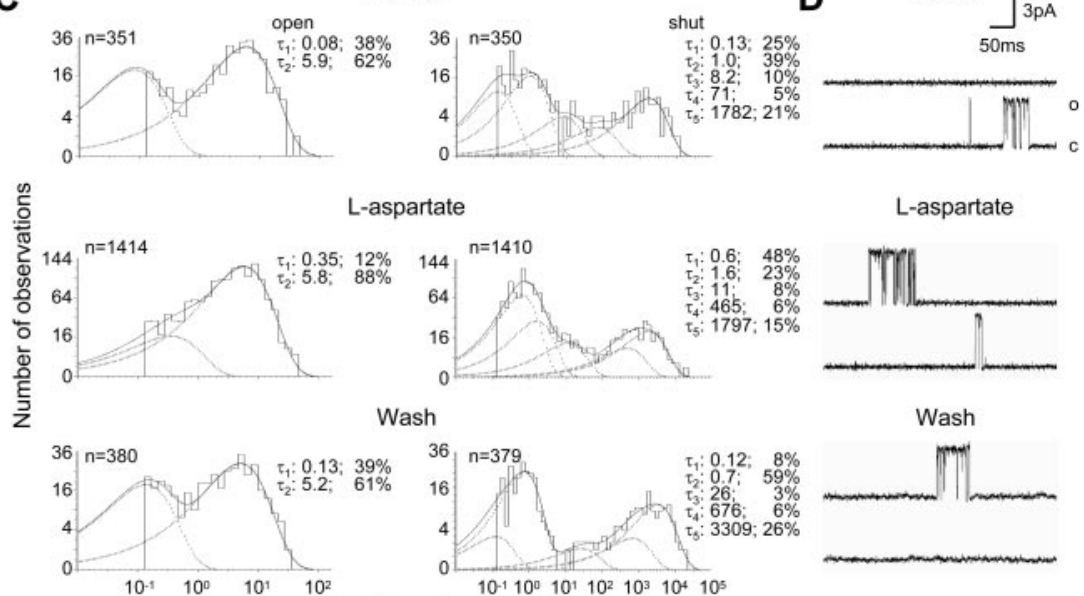

Dwell-time (ms)
E $\quad 0 \mathrm{mMCa}^{2+}$

(7)

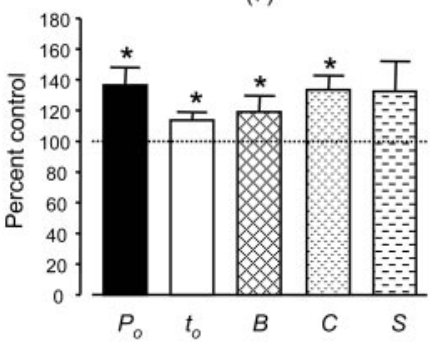

-aspartate

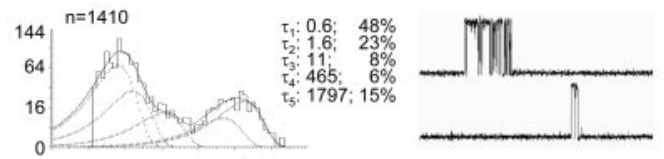

Wash

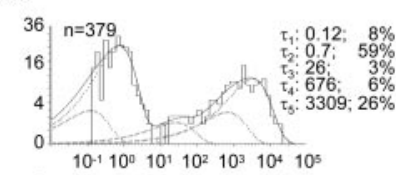

(6)

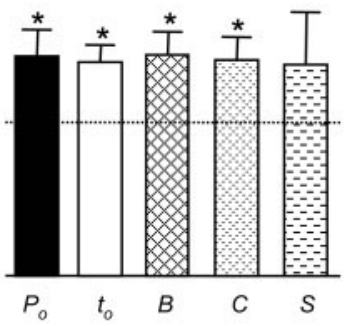

1. $2 \mathrm{mM} \mathrm{Ca}^{2+}$

(6)
Figure 6. Role of $\mathrm{Ca}^{2+}$ in the upregulation of NMDA channel gating by remote NMDA receptors. $A$, An example of NMDA channel open probability $\left(P_{0} ;\right.$ bin, $\left.10 \mathrm{sec}\right)$ recorded from neurons pretreated with BAPTA-AM (10 $\mu \mathrm{m}$ for $\left.4 \mathrm{hr}\right)$ and bathed with the $\mathrm{Ca}^{2+}$-free extracellular solution by using recording pipettes filled with the same $\mathrm{Ca}^{2+}$-free extracellular solution except that it contained $10 \mu \mathrm{m}$ NMDA. The break during the recording was required for adjusting the patch potential to $70 \mathrm{mV}$ from the NMDA channel reversal potential after L-aspartate $(500 \mu \mathrm{m})$ was applied to neurons. $B$, The graph shows the $I-V$ relationship for single-channel currents before (open circles) and during (filled circles) L-aspartate application. The depicted lines represent least-squares regression lines. C, Dwell-time histograms of open and shut times were compiled before (top), during (middle), and after (bottom) the bath application of L-aspartate. In the dwell-time histograms, the solid line shows the Marquardt least-squares fit for the histogram, the dashed lines indicate individual exponential components, and $n$ is the number of events. $\tau$, Time constant; the percentage values indicate relative areas of each component. $D$, Representative single-channel current traces are illustrated before, during, and after the application of L-aspartate. 0, Open level; $c$, closed level. $E$, Summarized data (mean \pm SEM) outlining the effects of remote NMDA receptor activation by the bath application of L-aspartate on $P_{0}$, mean open time $\left(t_{0}\right)$, burst $(B)$, cluster $(C)$, and supercluster $(S)$ lengths of NMDA channels recorded in neurons bathed with extracellular solution containing $1.2,0.3$, or $0 \mathrm{~mm} \mathrm{Ca}^{2+}$. Recording pipettes were filled with the same extracellular solution used for bathing neurons except that it contained $10 \mu \mathrm{M}$ NMDA. The neurons bathed with the bath solution containing $0 \mathrm{~mm} \mathrm{Ca}^{2+}$ were pretreated with BAPTA-AM for $4 \mathrm{hr}$. Values in parentheses indicate the number of patches tested; ${ }^{*} p<0.05$ (Wilcoxon test).

influx during NMDA receptor activation and that the increased $\mathrm{Na}^{+}$influx may increase $\mathrm{Ca}^{2+}$ influx significantly on one hand but on the other hand also mask $\mathrm{Ca}^{2+}$-induced inhibition of NMDA receptors. Thus the $\mathrm{Na}^{+}$-dependent upregulation effect may play a dominant role in the regulation of the cross talk between NMDA receptors (Fig. 7).

When neurons were bathed with a standard extracellular solution, the activation of remote NMDA receptors significantly increased overall channel open probability, mean open time, and the duration of bursts and clusters. The increases of the long- 


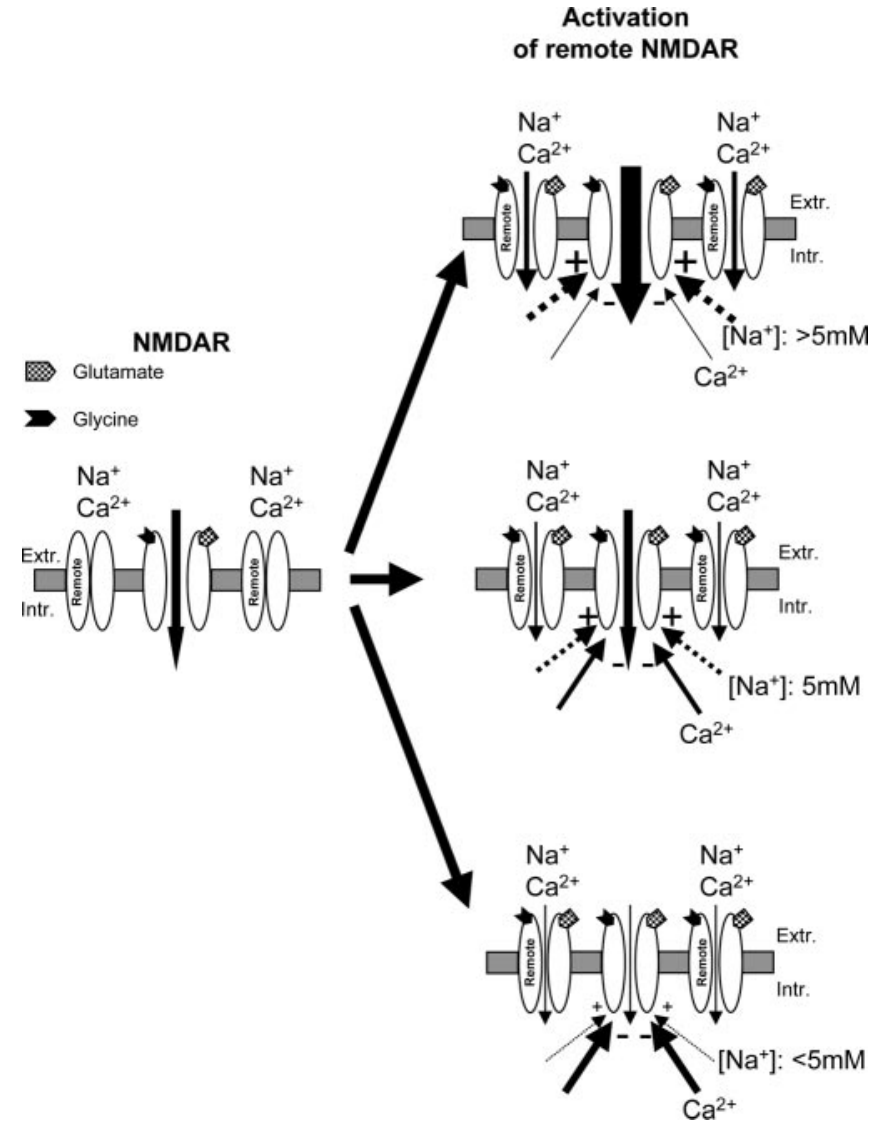

Figure 7. An overview of the effects of $\mathrm{Na}^{+}$and $\mathrm{Ca}^{2+}$ influx in the regulation of NMDA channel gating by remote NMDA receptors. NMDA channel activity may be upregulated or downregulated by remote NMDA receptors, depending on the amount of $\mathrm{Na}^{+}$and $\mathrm{Ca}^{2+}$ influx. If $\mathrm{Na}^{+}$influx is blocked, $\mathrm{Ca}^{2+}$ influx induced by the activation of remote NMDA receptors may inhibit NMDA channel gating. This $\mathrm{Ca}^{2+}$-induced inhibition of NMDA receptors can be prevented by a small $\mathrm{Na}^{+}$influx, which increases $\left[\mathrm{Na}^{+}\right]_{\mathrm{i}}$ by $5 \pm 1 \mathrm{~mm}$. The $5 \pm 1 \mathrm{~mm}$ increase in $\left[\mathrm{Na}^{+}\right]_{i}$ is apparently a critical threshold for controlling the $\mathrm{Ca}^{2+}{ }^{2+}$ influx-induced inhibition of NMDA channel activity during remote NMDA receptor activation. NMDA channel gating may be decreased if $\mathrm{Na}^{+}$influx during the activation of remote NMDA receptors is less than that required to overcome the effects induced by $\mathrm{Ca}^{2+}$ influx, whereas NMDA channel gating may be potentiated by the activation of remote NMDA receptors if $\mathrm{Na}^{+}$influx is more than that required to overcome the effects induced by $\mathrm{Ca}^{2+}$ influx. Because there is a large $\mathrm{Na}^{+}$influx during NMDA receptor activation under physiological conditions, the $\mathrm{Na}^{+}$-dependent upregulation effect plays a dominant role in the regulation of NMDA channel gating by NMDA receptor cross talk. Remote, Remote NMDA receptors; NMDAR, NMDA receptors; Extr., extracellular; Intr., intracellular.

open and short-closing components during the activation of remote NMDA receptors may underlie the increases in overall channel open probability and burst and cluster activities. Because we found that the bath application of NMDA or L-aspartate produced no change in the number of NMDA receptors detected on the cell surface (data not shown), which was consistent with that reported in a previous study (Nong et al., 2003), and that there was no change in the mean length of a single run of openings with no double openings (Colquhoun and Hawkes, 1990), it is unlikely that the number of NMDA channels on the membrane patch during the upregulation of remote NMDA channels is altered.

NMDA receptors are distributed widely on the cell surface, with locations on both the synaptic and extrasynaptic regions of central neurons. Our observations show that single NMDA channel gating may be regulated by the activation of remote NMDA receptors, which can result in changes in ensemble NMDA cur- rents. Bregestovski and his colleagues (Medina et al., 1996) found that single NMDA channel activity recorded in cell-attached patches may be downregulated after the washout of NMDA, which was bath applied to neurons. These findings support our suggestion that the activity of individual NMDA channels may behave differently when their neighboring NMDA receptors are activated (Fig. 7).

Although technical difficulties preclude the direct observation of remote NMDA receptor activation effects on the activity of an individual NMDA receptor located at the synapse, we were able to assess the regulation of synaptic function by activation of remote NMDA receptors via the use of simulation experiments. Supercluster current traces recorded before and during the activation of remote NMDA receptors were aligned at the start of the first openings and subsequently were summed to produce an ensemble current. The decay of normalized ensemble currents was significantly different before and during the activation of remote NMDA receptors. Depending on the amount of $\mathrm{Na}^{+}$and $\mathrm{Ca}^{2+}$ influx through activated remote NMDA receptors, there can be a prolonged or shortened decay in ensemble currents. Thus this type of data provides additional evidence to support the concept that the cross talk between NMDA receptors, which is mediated by a functional $\mathrm{Na}^{+}-\mathrm{Ca}^{2+}$ interaction, may be a novel mechanism regulating synaptic responses.

\section{References}

Bibby KJ, McCulloch CA (1994) Regulation of cell volume and $\left[\mathrm{Ca}^{2+}\right]_{\mathrm{i}}$ in attached human fibroblasts responding to anisosmotic buffers. Am J Physiol 266:C1639-C1649.

Callaway JC, Ross WN (1997) Spatial distribution of synaptically activated sodium concentration changes in cerebellar Purkinje neurons. J Neurophysiol 77:145-152.

Choi DW (1993) NMDA receptors and AMPA/kainate receptors mediate parallel injury in cerebral cortical cultures subjected to oxygen-glucose deprivation. Prog Brain Res 96:137-143.

Colquhoun D, Hawkes AG (1990) Stochastic properties of ion channel openings and bursts in a membrane patch that contains two channels: evidence concerning the number of channels present when a record containing only single openings is observed. Proc R Soc Lond B Biol Sci 240:453-477.

Colquhoun D, Sakmann B (1985) Fast events in single-channel currents activated by acetylcholine and its analogues at the frog muscle end-plate. J Physiol (Lond) 369:501-557.

De Koninck Y, Mody I (1994) Noise analysis of miniature IPSCs in adult rat brain slices: properties and modulation of synaptic $\mathrm{GABA}_{\mathrm{A}}$ receptor channels. J Neurophysiol 71:1318-1335.

Dingledine R, Borges K, Bowie D, Traynelis SF (1999) The glutamate receptor ion channels. Pharmacol Rev 51:7-61.

Edmonds B, Colquhoun D (1995) Mechanisms of activation of glutamate receptors and the time course of excitatory synaptic currents. Annu Rev Physiol 57:495-519.

Ehlers MD, Zhang S, Bernhardt JP, Huganir RL (1996) Inactivation of NMDA receptors by direct interaction of calmodulin with the NR1 subunit. Cell 84:745-755.

Gibb AJ, Colquhoun D (1992) Activation of N-methyl-D-aspartate receptors by L-glutamate in cells dissociated from adult rat hippocampus. J Physiol (Lond) 456:143-179.

Hille B (1992) Ionic channels of excitable membranes, Ed 2. Sunderland, MA: Sinauer.

Krupp JJ, Vissel B, Thomas CG, Heinemann SF, Westbrook GL (1999) Interactions of calmodulin and $\alpha$-actinin with the NR1 subunit modulate $\mathrm{Ca}^{2+}$ dependent inactivation of NMDA receptors. J Neurosci 19:1165-1178.

Kyrozis A, Albuquerque C, Gu J, MacDermott AB (1996) $\mathrm{Ca}^{2+}$-dependent inactivation of NMDA receptors: fast kinetics and high $\mathrm{Ca}^{2+}$ sensitivity in rat dorsal horn neurons. J Physiol (Lond) 495:449-463.

Lei G, Xue S, Chery N, Liu Q, Xu J, Kwan CL, Fu Y, Lu YM, Liu M, Harder KH, Yu X-M (2002) Gain control of N-methyl-D-aspartate receptor activity by receptor-like protein tyrosine phosphatase alpha. EMBO J 21:2977-2989. 
Lieberman DN, Mody I (1994) Regulation of NMDA channel function by endogenous $\mathrm{Ca}^{2+}$-dependent phosphatase. Nature 369:235-239.

Mayer ML, Westbrook GL (1987) The physiology of excitatory amino acids in the vertebrate central nervous system. Prog Neurobiol 28:197-276.

McBain CJ, Mayer ML (1994) N-methyl-D-aspartic acid receptor structure and function. Physiol Rev 74:723-760.

McLarnon JG, Curry K (1990) Single channel properties of the N-methylD-aspartate receptor channel using NMDA and NMDA agonists: on-cell recordings. Exp Brain Res 82:82-88.

Medina I, Filippova N, Bakhramov A, Bregestovski P (1996) Calcium-induced inactivation of NMDA receptor channels evolves independently of run-down in cultured rat brain neurones. J Physiol (Lond) 495:411-427.

Mody I, MacDonald JF (1995) NMDA receptor-dependent excitotoxicity: the role of intracellular $\mathrm{Ca}^{2+}$ release. Trends Pharmacol Sci 16:356-359.

Mulkey RM, Endo S, Shenolikar S, Malenka RC (1994) Involvement of a calcineurin/inhibitor-1 phosphatase cascade in hippocampal long-term depression. Nature 369:486-488.

Nicholls D, Attwell D (1990) The release and uptake of excitatory amino acids. Trends Pharmacol Sci 11:462-468.

Nong Y, Huang YQ, Ju W, Kalia LV, Ahmadian G, Wang YT, Salter MW (2003) Glycine binding primes NMDA receptor internalization. Nature 422:302-307.

Paoletti P, Ascher P (1994) Mechanosensitivity of NMDA receptors in cultured mouse central neurons. Neuron 13:645-655.

Rose CR, Konnerth A (2001) NMDA receptor-mediated $\mathrm{Na}^{+}$signals in spines and dendrites. J Neurosci 21:4207-4214.
Rose CR, Ransom BR (1997) Regulation of intracellular sodium in cultured rat hippocampal neurones. J Physiol (Lond) 499:573-587.

Stern P, Cik M, Colquhoun D, Stephenson FA (1994) Single channel properties of cloned NMDA receptors in a human cell line: comparison with results from Xenopus oocytes. J Physiol (Lond) 476:391-397.

Taylor CP, Dudek FE (1982) Synchronous neural afterdischarges in rat hippocampal slices without active chemical synapses. Science 218:810-812.

Tong G, Shepherd D, Jahr CE (1995) Synaptic desensitization of NMDA receptors by calcineurin. Science 267:1510-1512.

Wang YT, Yu X-M, Salter MW (1996) $\mathrm{Ca}^{2+}$-independent reduction of $\mathrm{N}$-methyl-D-aspartate channel activity by protein tyrosine phosphatase. Proc Natl Acad Sci USA 93:1721-1725.

Wechsler A, Teichberg VI (1998) Brain spectrin binding to the NMDA receptor is regulated by phosphorylation, calcium, and calmodulin. EMBO J 17:3931-3939.

Wong EH, Kemp JA (1991) Sites for antagonism on the N-methyl-Daspartate receptor channel complex. Annu Rev Pharmacol Toxicol 31:401-425.

Yu X-M, Salter MW (1998) Gain control of NMDA receptor currents by intracellular sodium. Nature 396:469-474.

Yu X-M, Askalan R, Keil GJI, Salter MW (1997) NMDA channel regulation by channel-associated protein tyrosine kinase Src. Science 275:674-678.

Zhang S, Ehlers MD, Bernhardt JP, Su CT, Huganir RL (1998) Calmodulin mediates calcium-dependent inactivation of $\mathrm{N}$-methyl-D-aspartate receptors. Neuron 21:443-453. 